\title{
P271: Knowledge of infection prevention and control during pregnancy in local health facilities in Bujumbura
}

\author{
R Paul-Claudel
}

From 2nd International Conference on Prevention and Infection Control (ICPIC 2013)

Geneva, Switzerland. 25-28 June 2013

\section{Introduction}

Nosocomial infection is a constant concern in the obstetric and surgical practice in both developing countries than in developed countries.

\section{Objectives}

To assess knowledge, attitudes and practices of the staff of maternity services in the prevention of nosocomial infection in three community health centers in Bujumbura.

\section{Methods}

A qualitative survey was conducted using a standardized questionnaire over 2 months with 76 health workers from three maternity wards of health facilities in the vicinity of all categories. Data collection consisted of two parts: first assessment of knowledge through a questionnaire and also the observation of attitudes and practices of personal hygiene.

\section{Results}

It was noted: In knowledge: Knowledge of the exact definition of nosocomial infection: 75\% (doctors), modes of transmission of infection (manu-portage): $50 \%$, hygiene protocols: $25 \%$, and procedures decontamination of contaminated equipment: $16 \%$. At the observation of practices:

Compliance with hand washing before and after childbirth: $50 \%$ Use of alcohol-based solutions: $20 \%$, antiquated equipment sterilization: $80 \%$ Compliance with the sterilization of equipment: $25 \%$ Circulation in delivery rooms disorganized: $100 \%$, perceived risk of blood contamination (uterus): $75 \%$, biomedical waste collected and decontaminated evil: $80 \%$, existence of incinerators:

Directeur de l'Offre et de la demande de soins, Bujumbura, Burundi
$33.3 \%$ and participation in training in personal hygiene: $50 \%$.

\section{Conclusion}

There is a high risk of infectious contamination in maternity services studied for both the staff and for parturient and their newborns.

\section{Competing interests}

None declared.

Published: 20 June 2013

doi:10.1186/2047-2994-2-S1-P271

Cite this article as: Paul-Claudel: P271: Knowledge of infection prevention and control during pregnancy in local health facilities in Bujumbura. Antimicrobial Resistance and Infection Control 2013 2(Suppl 1):P271.
Submit your next manuscript to BioMed Central and take full advantage of:

- Convenient online submission

- Thorough peer review

- No space constraints or color figure charges

- Immediate publication on acceptance

- Inclusion in PubMed, CAS, Scopus and Google Scholar

- Research which is freely available for redistribution

Submit your manuscript at www.biomedcentral.com/submit
() Bïomed Central

\section{Biomed Central}

